https://doi.org/10.18485/iipe_response2covid19.2021.ch13

\title{
ECONOMIC IMPACT OF COVID-19: A DETERMINING FACTOR OF CURRENT GLOBAL ECONOMIC TRENDS
}

\author{
Antoaneta Vassileva ${ }^{1}$ \\ Milica Simić ${ }^{2}$
}

Abstract: The purpose of this chapter is to analyse the impact of the COVID19 pandemic on global economic developments and outline the tendencies to which it led. The research is based on the assumption that the virus is likely to be as contagious economically as it is medically contagious. Studying the world's leading economies (the US, the European Union and China) from the beginning to the end of 2020, two groups of consequences emerge. First, the introduction of restrictive measures at the start of the pandemic imposed social distancing and reduced the movement of people and goods, which in turn had a major effect on the collapse of the services' sector and the supply chains. Second, the exponential growth of infected people and the speed of the spread of the virus forced the world's leading economies to apply more restrictive measures in the form of national lockdowns, curfews, and quarantines, resulting in the total paralysis of the economy and a rapid decline in GDP. Desk research has been applied in the analysis, based on available external and internal sources. Data from national statistical institutes and international organizations have been used. The results clearly indicate that the adopted economic measures became a determining factor for the world's leading economies not to enter a great recession and laid the foundations of the global economic trends. The beginning of immunization of the population opens the way to an

\footnotetext{
${ }^{1}$ Professor, Faculty of International Economics and Politics, University of National and World Economy, Sofia, Bulgaria, a.vasileva@unwe.bg.

${ }^{2}$ Professor, Faculty of Finance, Banking and Audit, Alfa BK University, Belgrade, Serbia,milica.simic@alfa.edu.rs.
} 
accelerated return to normal economic activities, a turn to sustainable development and economic growth.

Keywords: COVID-19, pandemic, global economy, US, European Union, China.

\section{INTRODUCTION}

Although it is difficult to determine exactly what the economic damage from the global coronavirus pandemic COVID-19 will be, there is a broad consensus among economists that it will have serious negative impacts on the global economy. Early estimates predicted that if the virus became a global pandemic, most of the major economies would lose at least $2.9 \%$ of their gross domestic product (GDP) by 2020 . This forecast has already been revised to a $4.5 \%$ GDP loss. To put this number into perspective, global GDP is estimated at about USD 87.55 trillion in 2019, meaning a 4.5\% drop in economic growth results in nearly USD 3.94 trillion in lost economic output (World Bank, 2021).

The shock caused by the coronavirus pandemic quickly became a global effect, causing several negative impacts to be synchronized. More than $90 \%$ of the global economy has experienced a reduction in GDP per capita. The shock spread through three key channels: disruption of the global supply chains, restricting international mobility and reducing international capital movements. The trade experienced a short-lived but deep plunge. In the first wave of the pandemic, trade declined sharply, giving an even greater effect to the economic downturn, but soon recovered, maintaining demand substitution through labour-intensive products.

The pandemic will have short-term and long-term macroeconomic effects. Macroeconomic costs and losses caused by it relate to the loss of gross domestic product in the countries affected by COVID-19, the growth of the unemployment rate in those countries, and the deterioration of other macroeconomic indicatorsfiscal indicators and indicators of external equilibrium - which will have an impact on their economic growth rates.

The shock caused by the coronavirus pandemic in the economy certainly showed that non-economic and non-financial factors can have very significant economic and financial effects at the global level and can appear as triggers for starting an economic recession. This will certainly contribute to paying much more attention to them in the future, both in economics and in conducting economic policy.

\section{METHODOLOGY}

The chapter examines the initial conditions in the transmission of the shock and the extent of the expected recovery, the assistance of the international 
organizations, and the measures undertaken by the states during the crisis. It also views the current economic trends determined as a consequence of the coronavirus pandemic. Beyond the actions of the international organizations, in some cases, COVID-19 has also resulted in inter-governmental cooperation in an effort to overcome shared challenges, so joint efforts to respond to the pandemic are the focus of attention.

The methodology of this study is based on a review of the existing economic literature on the economic and fiscal impact of the coronavirus pandemic on the world's leading economies and preliminary recovery estimates. The analysis covers the world's leading economies: the United States, the European Union and China. The goal is to analyse the GDP trends of these countries in 2020, as well as the first quarter in 2021. Also, the set of measures taken by these countries in order to mitigate the economic effects caused by COVID-19 has been explored. Desk research, based on available external and internal sources, has been applied in the analysis. Data from the reference national statistical institutes of the countries surveyed have been used. It is difficult to overcome the limitations connected with the lack of actual papers, especially on China, so current data have been retrieved mainly from the documents of the IMF and other international organizations.

\section{ECONOMIC IMPACT OF THE CORONAVIRUS PANDEMIC}

The economic setup in the world is still at a high level of fluctuation and uncertainty. Ruinous effects due to the pandemic deepen the perception of risk and instability on the financial markets of the world's leading economies. The global health crisis caused by COVID-19 has brought about major economic disruptions and inflicted a dramatic slowdown in the global economy (IMF, 2020). Different countries have been affected differently by the pandemic virus, so they have reacted in various ways in terms of policies to address this crisis (Hale et al., 2020; ECPresscorner, 2020). The hardest-hit countries are those that rely largely on services, primarily tourism and hospitality because it is a sector of extreme sensitivity to the COVID-19 pandemic. The spread of the pandemic has left national economies and businesses to calculate costs, while governments are struggling with new locking measures to combat the expansion of the virus. Despite the development of new vaccines, many are still wondering what recovery might look like. Large shifts in stock markets, where stocks and companies are bought and sold, can affect the value of pensions or individual savings accounts. The FTSE, the Dow Jones industrial average and the Nikkei recorded huge declines as the number of COVID-19 cases grew in the first months of the crisis. The major Asian and US stock markets recovered after the announcement of the first vaccine in November, but 
the FTSE is still in the negative zone. The FTSE fell by $14.3 \%$ in 2020 , its worst performance since 2008. In response, central banks in many countries have cut interest rates. This should, in theory, make borrowing cheaper and stimulate spending to stimulate the economy (IMF, 2020).

With the introduction of epidemiological and quarantine measures, the three biggest economies, the United States, China and the European Union, have suffered a huge impact on their economic growth and development (Figure 1). The first economic losses were recorded by the services industry due to reduced demand caused by the restriction measures on the mobility of people and lockdowns in certain countries. Also, small and medium-sized companies without sufficient financial reserves failed to cope with the new situation. At a global level, there is a decline in aggregate supply and demand. Many countries are introducing national lockdowns, restricting the movement of their citizens, curfews and other isolation measures.

Figure 1. Real GDP growth - China, US, World, Eurozone
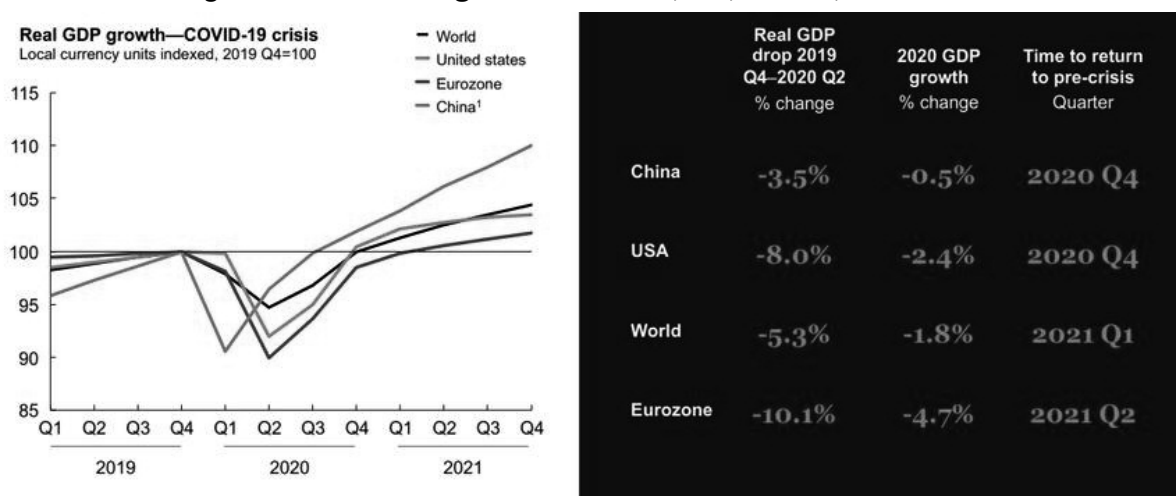

Source: Soebandrija, 2020, p. 142

The world's first economy, the United States, is experiencing slight economic growth and recovery. In the third quarter of 2020, GDP grew by $33.1 \%$ and represented the highest recorded growth, after a record decline in the second quarter of $31.4 \%$. Measures to help the population and the economy were given a strong financial boost, so personal consumption had the highest growth and was a driver of development for the rest of the economy. Personal consumption increased by $40.7 \%$, while gross private investment increased by $83 \%$, with a growth of $59.3 \%$ in the housing sector (US GDP Growth Rate, 2020). Also, the scope and speed of the interventions of the Federal Reserve (Fed) were more significant than those of 
the ECB. In mid-March, the Fed lowered the reference interest rate to the range from $0 \%$ to $0.25 \%$ - the level it was at from 2008 to 2015 . The Fed has also increased the amount of funds it holds in bonds. They also came out with a program of measures worth USD 2.3 billion to support local governments and small and medium-sized enterprises. Real gross domestic product increased at an annual rate of $6.4 \%$ in the first quarter of 2021 , reflecting a continued economic recovery, the reopening of facilities, and continued government response to the COVID-19 pandemic. In the fourth quarter of 2020, real GDP grew by $4.3 \%$. On the manufacturing side, private goods industries grew by $5.4 \%$, led by computer and electronic products, processed metal products and machinery. Industries producing private services grew by $7.7 \%$, led by data processing, publishing on the Internet and other information services, and the government grew by $0.2 \%$. Analysts show that the economy in the second quarter is expanding by about $9 \%$, while the recovery continues, although growing price pressures are already burdening some sectors, i.e., the housing market (Bureau of Economic Analysis, 2021).

After a record drop in China's GDP in the first quarter of 2020 of $-6.8 \%$, the largest in the last decade, the third quarter recorded a much better picture. The Chinese economy recorded growth of $4.9 \%$ in the third quarter of 2020 , which was still below the expected growth of 5.2\%. Despite lower-than-expected growth, consumption growth and recovery of industrial activity supported by government financial measures have been undertaken. The activity of the retail sector in September recorded a growth of 3.3\% and represented the highest growth of this sector since the beginning of the year. Industrial production increased by $6.9 \%$. The total economy grew by $0.7 \%$, with the primary industry growing by $2.3 \%$, and the secondary industry by $0.9 \%$ and the services sector by $0.4 \%$. Growing global demand for medical equipment and home-based technology has increased exports, while government support includes higher fiscal spending (National Bureau of Statistics of China, 2020). The Chinese National Bureau of Statistics released data for the first quarter of 2021 showing accelerated GDP growth of $18.3 \%$, compared to $6.5 \%$ in the fourth quarter of 2020 . The main driver of growth in the first quarter was industry and construction, which grew by $24.4 \%$, while services grew by $15.6 \%$. However, monthly data suggest that the growth of services has taken off, while the growth of production is declining. In the coming quarters, we expect that the growth of consumer demand will be moderate because a significant part of the "backlog of demand" has already been realized, while the growth of production will slow down. In addition, reduced support for the policy from the monetary but also the fiscal side will keep the cover on economic growth. On the fiscal side, China's recent government budget targets a fiscal deficit of $3.2 \%$ of GDP, which is relatively conservative (National Bureau of Statistics of China, 2021). 
The second quarter of 2020 in the EU was marked by measures to combat COVID-19, which affected the reduction of GDP at the level of the entire Union. In the second quarter, the EU recorded a decline of $11.9 \%$ and represented the largest decline in GDP since 1995. In the second quarter, there was a sharp decline in labour productivity by $2.9 \%$. Exports decreased to $18.8 \%$, while imports decreased by $17.8 \%$ (Eurostat, 2020). The Union has suffered heavy financial losses due to the shock caused by the pandemic. France and Germany, as the two largest economies in the EU, announced a joint proposal to finance the recovery of the EU economy in mid-May. According to the proposal, it is planned to finance the development of the EU Health Strategy, to finance the Recovery Plan for Solidarity and Growth, to stimulate the green economy and digitalization and to stimulate the single market. Despite criticism of such a generous program coming from more "thrifty" members like Austria, Denmark, and the Netherlands, the European Commission came up with a Recovery Program at the end. In the first quarter of 2021, seasonally adjusted GDP decreased by $0.3 \%$ in the Euro area and by $0.1 \%$ in the EU. Compared to the previous quarter, according to an estimate published by Eurostat, the statistical office of the European Union, these declines follow a drop in the fourth quarter of $2020(-0.6 \%$ in the Eurozone and- $0.4 \%$ in the EU) after a strong recovery in the third quarter of 2020. Household final consumption expenditures had a negative contribution to GDP growth in both the Euro area and the EU, while contributions from gross fixed capital formation and changes in inventories were positive. The contribution of the external balance was slightly positive for the Euro area and neutral for the EU, while the contributions from government final expenditures were neutral in both zones (Eurostat, 2021).

The pandemic and its economic consequences are still uncertain and may be revised. One of the key roots of uncertainty stems from the fact that efforts and measures to stop the spread of the pandemic could remain in place for longer than expected. High-frequency indicators for the first quarter of leading economies suggest a recovery in global economic activity, but all of this may be called into question as new strains of the virus spread globally.

\section{ECONOMIC MEASURES UNDERTAKEN BY INTERNATIONAL ORGANIZATIONS AND GOVERNMENTS}

It is obvious that the crisis took a severe toll on the economies all over the world. It forced international organizations and national governments to implement diverse measures to curtail the pandemic and support the economy (Vassileva, Simić, 2021b, p. 33). 
The United Nations has mobilized its full capacity to support national authorities in developing public health preparedness and response plans to the COVID-19 crisis. The UNDP and its country offices worldwide have been working in close collaboration with specialized UN agencies to assess the socio-economic impacts of the COVID-19 pandemic. They have prepared assessment reports which contain the preliminary findings of regional and country analyses as well as recommendations for their recovery policy (UNDP, 2020). While official development assistance was being directed towards humanitarian and health measures to respond to COVID-19, the UNDP redirected its own funding to kickstart vital recovery efforts in fragile contexts.

In order to recover from this crisis stronger and launch a new path, the UN called for a USD 2.5 trillion support package for developing countries to deal with the coronavirus shock (UNCTAD, 2020b). The financial assistance was allocated as follows:

-USD 1 trillion should be made available through the expanded use of special drawing rights.

-USD 1 trillion of debts owed by developing countries should be cancelled.

- USD 500 billion needed to fund a Marshall Plan for health recovery and dispersed as grants.

The world's leading economies applied restrictive measures in the form of national lockdown, curfew, and quarantine together with economic measures, which resulted in mitigating the detrimental effects. As it has already been mentioned, in order to help the economy after the COVID disaster, the US declared USD 2.3 trillion Relief and Funding Bill, signed by President Donald Trump in 2020, and another 1.9 trillion Relief Bill, signed by President Joe Biden. In the first quarter of 2021, government payments, such as direct economic consequences, extended unemployment benefits, and payroll loans, were distributed to households and businesses through the coronavirus Response and Assistance Act and the American Rescue Plan (ARP). The ARP includes provisions on aid to state and local governments, hard-hit industries and communities, tax changes affecting individuals and businesses, and other provisions.

According to the consulting company White \& Case (2020), China has promulgated a package of financial policies to ease the financial distress of enterprises caused by the outbreak of the coronavirus pandemic. The financial policies include providing loans with preferential conditions through financial institutions to certain frontline companies, reducing the costs of financing guarantee services, postponing the repayment of loans, optimizing corporate bond issuance procedures and facilitating cross-border financing. Among these financial policies, 
the Ministry of Finance also released industry-specific policies jointly with the Civil Aeronautics Administration of China to provide financial support to airlines during the COVID-19 outbreak. To reduce the financing costs of agricultural enterprises and SMEs, a Circular on Re-lending and Re-discounting to Promote Orderly Resumption of Operations and Production was promulgated, setting forth the detailed loan facilitation and re-discounting schemes which allocate a total amount of CNY 500 billion to support agricultural enterprises and SMEs. Apart from that, China provided assistance to more than 80 countries in the world.

To reset the economy that has been ruined by COVID-19 and help repair the social damage caused by the pandemic, the European Commission, the European Parliament and EU leaders have agreed on a recovery plan that is targeted to lead the way out of the crisis and lay the foundations for a modern and more sustainable Europe. The EU's long-term budget for 2021-2027, coupled with NextGenerationEU, the temporary instrument designed to boost the recovery, is the largest stimulus package ever financed through the EU budget. The EU announced a package of 540 billion and later approved Euro 672.5 billion for recovery and a full package of Euro 1.8 trillion (DW, 2021). According to the program, where the recovery is based on solidarity and the budget is focused on the future, as much as $2 / 3$ of the funds would be non-refundable money to members, while the rest of the money would be loans on favourable terms offered in international financial markets (European Commission, 2020).

To support their national economies in coping with the immediate repercussions of the health crisis, the member states of the EU have implemented a wide range of measures, mainly of fiscal nature. The focus was on mitigating the short-term impact of government restrictions, including falling demand and production, income reductions and unemployment. These encompass four main typologies: a) discretionary support: measures targeting expenditure (e.g. income and employment support, interest subsidies, credit loss provisions, exceptional spending on healthcare and research), and revenues (e.g. tax payment reliefs and cuts in tax rates); b) financial instruments: measures aimed at supporting enterprises' cashflow or solvency position, through liquidity funnelling through loans or equity injections; c) guarantees: measures aimed at supporting enterprises' liquidity position through guaranteed debts granted by a financial institution undertaken by governments; and d) tax payment: measures aimed at temporarily increasing the liquidity position of enterprises through deferrals of taxes or social contribution payments. By June 2020, almost 1,250 fiscal measures accounting for about Euro 3.5 trillion, namely 27\% of EU27 GDP estimated for 2020, were adopted by the member states with the objective of mitigating both the health and economic effects of the pandemic (de Vet et al.). Among these, 59\% of the measures consist of guarantees, $19 \%$ and $5 \%$ of discretionary stimulus measures targeting expenditure and revenues, respectively, $11 \%$ of financial instruments and 
$6 \%$ of tax payment measures. The nature of the measures varies considerably across the member states, and their volumes can be directly correlated to the amount foreseen by the state aid schemes approved at the EU level, which also vary substantially across the member states. The largest fiscal packages were implemented by Germany, whose package amounted to about $43 \%$ of the country's GDP, followed by Italy (37\% of national GDP), France (23\%) and Spain (22\%). Lithuania represents a notable exception with a package worth $29 \%$ of national GDP despite the relatively low volume of its state aid scheme. The member states that received smaller fiscal packages include Slovakia (5\%) and Romania (5\%). Bulgaria received the smallest package of all (2\%), combined with unsuccessful crisis management - poor organization, incompetence, and potential conflict of interest (Atanasov, 2021).

The second step in combating the coronavirus consequences is the European Green Deal, which turns out to be a gateway to a green economy (EC, 2020). It presents a roadmap for making the EU's economy sustainable by turning climate and environmental challenges into opportunities across all policy areas. It aims to boost the efficient use of resources by moving to a clean, circular economy and stop climate change, revert biodiversity loss and cut pollution. It outlines the investments needed and financing tools available and explains how to ensure a just and inclusive transition. The European Green Deal covers all sectors of the economy, notably transport, energy, agriculture, buildings, and industries such as steel, cement, ICT, textiles and chemicals (EC, 2019). It launches a strategy for a climateneutral, resource-efficient and competitive economy, integral to the Commission's strategy to implement the United Nations 2030 Agenda on sustainable development. The circular economy is considered a key approach in the process of transition to a sustainable economy model and a way to achieve certain SDGs (Bogetić et al., 2021, p. 65). Scaling up the circular economy from front-runners to the mainstream economic players makes a decisive contribution to achieving climate neutrality by 2050 and decoupling economic growth from resource use, while ensuring the long-term competitiveness of the EU and leaving no one behind (EC, 2020). In the post-COVID-19 scenario, the circular economy can become the new normal. It can help address unsustainable trends and find adequate solutions towards a green recovery (Vassileva, Simić, 2021a, p. 32).

\section{CURRENT ECONOMIC TRENDS DETERMINED AS A CONSEQUENCE OF THE CORONAVIRUS PANDEMIC}

It is too early to estimate the total effects of the coronavirus pandemic. Researchers in many fields are busy exploring its positive and negative consequences on a national and international level, comparing it with similar 
phenomena. Surely, it will determine the current economic trends for a long time in the following direction:

\section{Reshaping globalization.}

The coronavirus pandemic contributed to the development of processes, reshaping globalization by stimulating the turnover of goods and services within regional groupings (Vassileva, Simić \& Stevanović, 2020, p.590). It has started a dramatic change in how multinational entities strategically approach their business model going forward as they deal with day-to-day operations. This crisis has forced businesses to change the way they operate, manage their workforce, adhere to governmental mandates, and react to customer and employee needs. The social activism of civil society showed its sensitiveness to issues that oppose the health of people with economic measures. The world will look different after COVID-19, and while the short-term outlook may be clouded by worsening economic indicators, history shows that markets and society can recover after a crisis with increased government involvement. The impact of the pandemic on the idea of globalism is more and more perceivable (Karajović, Kaličanin\&Kaličanin, 2021, p. 319). “During pandemics, complex interdependence renders connectivity more dangerous, agents more reluctant to depend on one another - precisely because one's local acts spill over their consequences far beyond", assumes Pereira da Silva Gama (2020). Other scholars like Weder di Mauro (2020, pp. 31-36) also argue that the COVID-19 crisis will provoke a $21^{\text {st }}$-century institutional retreat and reframe globalization.

However, due to the current pandemic of COVID-19, the four freedoms of the EU Internal Market have been severely restricted. The EU countries took precautionary measures to protect the health and safety of their citizens. Most businesses were shut down, transportation was restricted, and the movement of people across borders was banned. This situation created inconvenient trends within the intra-EU supply chains, as well as in intra-EU trade. The latest projections point out that the world health crisis will result in a decline of 9.2\% in EU exports and $8.8 \%$ in EU imports from third countries by the end of 2020. The trade diversion effect is strongly present in the case of the EU, meaning that the EU is trading more with partners within the EU rather than with trade-partners outside the EU (Makrevska, Kikerkova \&Toshevska-Trpchevska, 2020, p. 138). The EU members diverted their trade to partner countries, as most of them do not have lower comparative costs than the world average. 


\section{Disruption of the supply chains}

Another aspect of the influence of the crisis is the change in the global supply chains. Value chain disruption remains a salient factor when the disease has become more widespread. The volume of trade has fallen more steeply in sectors characterized by internationalized and complex value chain linkages, particularly in electronics and automotive products (Vassileva, Simić \& Stevanović, 2020, p.593). The COVID-19 pandemic unveiled weaknesses, as many businesses were initially unable to cope with shortages in supplies caused by closed borders and manufacturing sites. Nevertheless, most supply chains quickly recovered and have been affected less severely during subsequent waves of infections. The overall view of experts is that value chains can be strengthened through increased diversification rather than reshoring/onshoring. The crisis accentuated the strategic importance of value chains such as microelectronics, autonomous driving, batteries, and artificial intelligence in light of the accelerating digital transformation and growing demand for electric vehicles. These value chains need to receive continued attention and support to ensure access to materials, investment, and skills (de Vet et al., 2021, p. 9).

The crisis has enhanced the development of humanitarian supply chains connected with the trade of medical appliances and pharmaceuticals. The value chain that received the most attention during the pandemics was the production of personal protective equipment. While traditionally not considered a strategic value chain, the COVID-19 and subsequent shortages of medical face masks caused by spikes in demand highlighted the importance of this equipment. While advanced economies such as Germany and other European countries have specialized in the high-tech medical devices sector, low-cost countries such as China and Malaysia have been the leading producers of protective equipment, including face masks. COVID-19 greatly affected this market as many countries boosted domestic output and imposed export restrictions. The EU was among those imposing new export restrictions (de Vet et al., 2021, p. 49). Countries also stressed the importance of keeping supply chains open, and in many cases, import tariffs on face masks were lifted. Overall, the responses of the EU and its Member States to the shortages were a mix of openness and protectionism. While domestic production was increased, the EU overall relied on imports, and buyers were able to find alternative sources from other non-traditional exporters of personal protective equipment at short notice. Moreover, domestic production is likely to decrease once demand decreases again, and factories return to their original business models. Reshoring in this value chain is unlikely due to required economies of scale, established regional supplier networks, and the higher wages and sustainability standards in the EU. Instead, openness and fair access to international markets through collaboration with third 
countries, while ensuring sufficient stockpiles of essential medical goods, proved to be the right way to deal with the crisis.

\section{Acceleration of digitalization and the green agenda}

The pandemic acted as an accelerator of digitalization. The differences in the severity of COVID-19 effects are partially explained by the ability of businesses to go digital. It gave impetus to e-commerce, e-banking, work from home, online education, distant medical assistance, etc., which require wider use of online activities. The implications of globalization for companies do not include only diversification of their international business operations all over the world and the boosting of new modes like e-business, but also other evolving views of the environment which take the form of "green business" and a new attitude towards renewable resources and alternative sources of energy (Vassileva, Talovic \& Stojadinovic, 2018, p.76). The commitments are clustered around three areas: providing an enabling environment by improving connectivity and promoting entrepreneurship, increasing learning and innovation by public and private actors, including by raising enrolment in education, employing more researchers and investing more in R\&D and transferring knowledge across borders, by expanding foreign direct investment in R\&D activities, strengthening online learning and increasing international cooperation.

One of the positive effects of COVID-19 is that it provoked a wider use of "green" business, "green" supply chains, "green" energy, etc. (Vassileva, Simić, 2021b, p.36). The green economy agenda promotes sustainable patterns of production and consumption - resource and energy-efficient, low-carbon and low waste, nonpolluting, safe and climate-resilient, phasing out toxic substances, using renewable energy sources, taking increased producer responsibility and reducing overall risks. The crisis has opened an immense opportunity to be used as a reset moment for the world and as a chance for the corporate sector to take leadership and embrace sustainability as a strategy for its own success and as a global target. The crisis forced consumers to re-assess their needs and way of life, and it allowed for a potential acceleration of the green agenda. For example, in the automotive sector, despite the decline in the demand for new vehicles, the impact of the pandemic on demand for electric vehicles seems to be much less severe. This also affects the forecasts positively for the rebound of the battery supply chain. Overall, the pandemic has increased the awareness of the benefits of the digital and green transition, which needs to be coupled with adequate investments and political drives (de Vet et al., 2021, p. 8). 


\section{CONCLUSION}

COVID-19 has shaken the global economic landscape. It has affected the economy mainly through declining exports, which influences global economic activity, a decrease in demand as a consequence of measures and policies of entry restrictions that reduced travel, and reduction in domestic private consumption, which impacts the slump in business operations.

Alongside the disastrous consequences, the COVID-19 pandemic has some positive effects. It showed the crucial role of collective action and the joint efforts of the governments. Beyond the actions of the international organizations, in some cases, COVID-19 has also resulted in inter-governmental cooperation to overcome the shared challenges and achieve the SDGs. Due to COVID-19, the EU suspended all the austerity measures of the Stability and Growth Pact, allowing the counties to use their budgets according to their national needs and helping them through different types of financial instruments. While it is still uncertain whether the COVID19 crisis will influence the orientation of the countries, i.e., if the countries use the funds properly and towards the strengthening of the Internal Market, for sure it will increase the importance of their regional policy. A change in the idea of globalism has been noted while increasing regional activities.

One of the key concepts of the analysis is that the virus is as economically "contagious" as it is medically "contagious". The results of the discussion clearly indicate that economic measures have significantly mitigated the effects of the pandemic but also provoked a decisive transition to a green economy which will be a subject of further research. Locks, quarantines and border closures after the pandemic have led to a reduction in air pollution through reduced travel and production. The follow-up of the study might include analysis of further sequences based on a quantitative approach for a longer period of time. Thus, recognizing COVID-19 primarily as a global catastrophe, it is obvious that the pandemic can inspire future changes with positive effects on the environment and a decisive turn to the green agenda, opening the way to an accelerated return to normal economic activities, a turn to sustainable development and economic growth. Digitalization and investments in innovations and R\&D, both outcomes and challenges of the pandemic, are critical for the future of countries and businesses. 


\section{REFERENCES}

Atanasov, V.(2021, April 12).Bulgaria's COVID-19 vaccination fiasco: excessive risks, mediocre results, Respublika, retrieved from https://respublica.edu.mk/en/ prikazni-od-regionot/bulgaria-s-covid-19-vaccination-fiasco-excessive-risksmediocre-results. Accessed 5 July 2021.

Bogetić, S., Đorđević, D., Ćočkalo, D., Đorđević, L., Bakator, M. (2021). The circular economy and global market challenge, Ecologica, Vol. 28, No.101, pp.65-71

Bureau of Economic Analysis, Gross Domestic Product (Third Estimate), GDP by Industry, and Corporate Profits (Revised), 1st Quarter 2021, retrieved from https://www.bea.gov/data/gdp/gross-domestic-product. Accessed 30 June 2021.

COVID-19: Chinese Government Financial Assistance Measures, White \& Case, retrieved from https://www.whitecase.com/publications/alert/covid-19chinese-government-financial-assistance-measures. Accessed 13 June 2021.

de Vet, J.M., Nigohosyan, D.,Núñez F. J. Gross, A-K., Kuehl, S.,Flickenschild, M.(2021).Impacts of the COVID19 pandemic on EU industries, Publication for the Committee on Industry, Research and Energy, Policy Department for Economic, Scientific and Quality of Life Policies, European Parliament, Luxembourg, retrieved from https://www.europarl.europa.eu/committees/ en/supporting-analyses. Accessed 15 May 2021.

EC (2020). Circular Economy Action Plan: The European Green Deal, EU, retrieved from https://ec.europa.eu/environment/circular-economy/pdf/new_circular_ economy_action_plan.pdf. Accessed 15 May 2021.

EC (2019). A European Green Deal, European Commission, retrieved from EU https://ec.europa.eu/info/strategy/priorities-2019-2024/european-greendeal_en. Accessed 15 April 2021.

European Council,COVID-19 coronavirus pandemic: the EU's response, EU, retrieved from https://www.consilium.europa.eu/en/policies/coronavirus/. Accessed 5 July 2021.

European Parliament passes 6725 billion Covid recovery fund. (2021, February 10), retrieved from https://www.dw.com/en/european-parliament-passes-6725billion-covid-recovery-fund/a-56528327. Accessed 20 May 2021.

Europe's moment: Repair and prepare for the next generation, retrieved from https://ec.europa.eu/commission/presscorner/detail/en/ip_20_940. Accessed 23 October 2020. 
EU (2020), The EU Green Deal - a roadmap to sustainable economies, retrieved from https://www.switchtogreen.eu/the-eu-green-deal-promoting-a-greennotable-circular-economy/, Accessed 15 April 2021.

GDP main aggregates and employment estimates for the second quarter of 2020, retrieved from https://ec.europa.eu/eurostat/web/national-accounts/ publications/news-releases, Accessed 20 October 2020.

GDP main aggregates and employment estimates for the first quarter of 2021, retrieved from https://ec.europa.eu/eurostat/web/main/news/euro-indicators. Accessed 29 June 2021.

Hale, T., Angrist, N., Kira. B., Petherick. A., Phillips, T., Webster, S. (2020). Variation in Government Responses to COVID-19. BSG Working Paper Series. BSG-WP2020/032 Version 6.0., retrieved from www.bsg.ox.ac.uk/covidtracker. Accessed 22 December 2020.

International Monetary Fund (2020). World Economic Outlook. October 2020: A Long andDifficult Ascent, Washington DC

Karajović, M., Kaličanin, M.,Kaličanin, Z.(2021).Impact of Covid-19 on international economic relations and international capital movement, Ecologica, 28(102), pp. 315-324.

Makrevska, D.E., Kikerkova, I.,Toshevska-Trpchevska, K. (2020). COVID-19 Challenges for EU Extra and Intra-regional Trade, in:Conference Proceedings: Economic and Business Trends Shaping the Future(137-146), Skopje, http://doi.org/10.47063 /EBTSF.2020.0011

National Bureau of Statistics of China, Preliminary accounting data on gross domestic product in the third quarter of 2020, retrieved from http://www.stats. gov.cn/tjsj/zxfb/202010/t20201020_1794939.html. Accessed 25 October 2020.

National Bureau of Statistics of China, Preliminary Accounting Results of GDP for the First Quarter of 2021, retrieved from http://www.stats.gov.cn/english/Press Release/202104/t20210420_1816603.html. Accessed 30 June 2021.

Pereira da Silva Gama, C. F. (2020). Reframing Globalization: COVID-19 and 21st Century Institutional Retreat, E-International Relations, retrieved from https://www.e-ir.info/2020/08/04/reframing-globalization-covid-19-and-21stcentury-institutional-retreat/. Accessed 30 June 2021.

Soebandrija, K.E.N. (2020). Operations Agility and Industrial Engineering Ambidexterity in Digital Era, KATA SAMBUTAN, Vol 1, pp.137-150, retrieved from https://www.researchgate.net/figure/Real-GDP-Growth-China-USA-WorldEurozone_fig2_341606404. Accessed 10 July 2021. 
UNCTAD (2020a). Impact of the COVID-19 Pandemic on Trade and Development. Transition to a New Normal, Geneva, retrieved from https://unctad.org/system/ files/official-document/osg2020d1_en.pdf. Accessed20 April 2021.

UNCTAD (2020b). UN calls for $\$ 2.5$ trillion support package for developing countries to deal with coronavirus shock, retrieved from https://unctad.org/pressmaterial/un-calls-25-trillion-support-package-developing-countries-dealcoronavirus-shock. Accessed 20 May 2021.

UNDP (2020). Brief\#2: Putting the UN Framework for Socio-economic Response to Covid-19 into Action: Insights, retrieved from https://www.undp.org/content /undp/en/home/covid-19-pandemic-response/socio-economic-impact-ofcovid-19.html. Accessed 22 April 2021.

United States GDP Growth Rate, retrieved from https://tradingeconomics.com/ united-states/gdp-growth. Accessed 30 October 2020.

Vassileva, A., Simić, M. (2021a). Covid-19 and Sustainable Development, in:Jovanović et al. (Eds.) The Impact of COVID-19 Pandemic on the Economy and the Environment in the Era of the Fourth Industrial Revolution (pp. 32-43), April 2224, 2021, Scientific and Professional Society for Environmental Protection of Serbia 'Ecologica', Belgrade.

Vassileva, A., Simić, M. (2021b). The Green Recovery of the Economy as a Positive Consequence of COVID-19 Crisis, Book of Proceedings of First International Scientific Conference Covid-19 and Challenges of the Business World (pp. 3144), March 25, 2021, Belgrade.

Vassileva, A., Simić, M., Stevanović, M. (2020).Implications of COVID-19 for International Business, Ecologica,27(100), pp. 589-596.

Vassileva, A., Talović, V.R.,Stojadinović, M. (2018). Geopolitical and Economic Challenges of the Globalized World. Norderstedt, LAP LAMBERT Academic Publishing.

Weder di Mauro, B. (2020). Macroeconomics of the flu, in: R. Baldwin, B.Weder di Mauro (Eds.) Economics in the Time of COVID-19. London, CERP Press, pp. 31-36.

World Bank (2021). Global Economic Outlook, January 2021: Muted Global Economic Recovery. January, Washington, DC. 